\title{
Hantavirus cardiopulmonary syndrome: a report of two cases
}

Sindrome cardiopulmonar por hantavírus: relato de dois casos

\author{
Marcos Lazaro Moreli ${ }^{1}$; Vivaldo Gomes da Costa 2 ; Daiane Pereira da Silva Novaes 3 ; Enia Cristina Flor ${ }^{3}$; \\ Juliana Freitas Silva ${ }^{4}$; Keila Rejane Guimarães Vilela ${ }^{5}$ Cácia Régia de Paula ${ }^{6}$
}

\begin{abstract}
Infection with hantavirus, from the family Bunyaviridae, causes hantavirus cardiopulmonary syndrome (HCPS) in the Americas. This highly lethal anthropozoonosis afflicts preferentially individuals in rural areas and is transmitted by aerosol of excreta from infected wild rodents. The aim of this study is to report the almost simultaneous occurrence of two cases of HCPS in the municipality of Jataí, state of Goiás, Brazil.
\end{abstract}

Key words: hantavirus; hantavirus infections; hantavirus pulmonary syndrome.

\section{INTRODUCTION}

The hantavirus cardiopulmonary syndrome (HCPS) was first reported in the United States, during an outbreak among Navajo Indians in $1993^{(1,3)}$. In the same period, Brazil also confirmed cases of hantavirus infection in the municipality of Juquitiba, state of São Paulo. Since then, HCPS has been described from Canada to Patagonia. It is classified as an emergent disease and a serious public health problem ${ }^{(4-6,11,16)}$.

In Brazil, hantaviruses Juquitiba, Araraquara, Laguna Negralike, Castelo dos Sonhos and Anajatuba have been described as causative agentes of $\operatorname{HCPS}^{(5,9)}$. Wild rodents host the virus, and each hantavirus strain is associate to a specific type of rodent of the Sigmodontinae ${ }^{(1,6)}$ subfamily. From 1993 to 2012, HCPS was reported in different regions of Brazil, with the greatest number of cases in the South (565), followed by regions Southeast (456), Central-West (395), North (88) and Northeast (14). A total of 1,573 confirmed cases, showing lethality of $40 \%{ }^{(2)}$.
As most viroses exhibit inespecific symptoms, the definite diagnosis must be established by differential laboratory tests, such as the serologic immunoglobulin M (IgM) enzyme-linked immunosorbent assay (ELISA), or the molecular methods ${ }^{(7-9,15)}$. However, the medical team may reach a diagnosis suggestive of hantavirus infection based on clinical data and epidemiological background, taking into account the rapid evolution of the disease, whose treatment must be immediate. The objective of this work is to report the occurence of two cases of HCPS in Jataí, in order to discuss the potential seriousness of the disease, underlining the importance of an early differential diagnosis.

\section{CASE 1}

A 29-year-old married male pig farmer of mixed race, resident in a rural area of Jataí (but born in Montes Altos, state of Maranhão), who had a smoking history, and was seemingly healthy before admission, went into the emergency ward of

First submission on $02 / 12 / 12$; last submission on $08 / 06 / 13$; accepted for publication on 18/06/13; published on 20/10/13

1. Doctorate in Medical Sciences from Faculdade de Medicina de Ribeirão Preto-Universidade de São Paulo (FMRP-USP); associate professor of Microbiology/Virology at

Universidade Federal de Goiás (UFG), campus Jataí.

2. Biomedical scientist; master's student in Applied Health Sciences at UFG.

3. Graduate in Biomedicine of UFG.

4. Biologist at UFG.

5. Biomedical scientist; senior technician at Laboratório Elzevir Ferreira Lima; director general of Hemocentro Regional de Jataí.

6. Master's degree in Public Health from UFG; coordinator of the Epidemiological Surveillance Center of the Municipal Health Office in Jataí. 
Centro Médico de Saúde Serafim de Carvalho (CMSSC) at 12h of August 31, 2012 with a 5-day history of symptoms. He presented sweating, cough, malaise, blood pressure of $80 \times 60 \mathrm{mmHg}$ and axillary temperature of $38.8^{\circ} \mathrm{C}$. He also reported chest pain and adynamia. Medication was immediately administered and a chest radiograph was obtained. Based on his clinical picture of serious bilateral pneumonia with septic shock, the diagnostic hipotheses were dengue fever, leptospirosis, hantavirus infection, or influenza A subtype H1N1.

Just after admission, the patient presented intense dyspnea, saturation of peripheral oxygen $\left(\mathrm{SpO}_{2}\right)$ of $74 \%$ (after 20 minutes, $\mathrm{SpO}_{2}$ of $82 \%$ ) and heart rate of 140 beats per minute (bpm). He was put on an oxygen mask with reservoir bag delivering oxygen at $10 \mathrm{l} / \mathrm{min}$, and treated with Rocefin ${ }^{\circledR}$, Claritromicina ${ }^{\circledR}$ and Tamiflu $^{\circledR}$. The required laboratory tests and their results are shown in the Table, where it is possible to observe that practically all analysed parameters differed from reference values. The patient was then referred to the intensive care unit (ICU).

Upon admission to the ICU, the patient's clinical state worsened, with intense dyspnea, sweating, cough that produced large amounts of yellow secretion, and lowered level of consciousness. $\mathrm{SpO}_{2}$ of $73 \%$. Before intubation, a reservoir mask was put on the patient, who was sedated with Dormonid ${ }^{\circledR}$, alongside $2 \mathrm{ml}$ of Fentanil ${ }^{\circledR}$. Chest radiograph showed bilateral diffuse pulmonary infiltrate with ill-defined opacity in the upper third of the lung (image not shown). At $20 \mathrm{~h} 45$, the patient's condition was even worse and he suffered a cardiac arrest. Cardiopulmonary resuscitation was performed with chest compression and intravenous drug administration. The patient died at $21 \mathrm{~h}$.

\begin{tabular}{|c|c|c|c|}
\hline \multicolumn{4}{|c|}{ TABLE - Patients' laboratory data required at hospital admission } \\
\hline Laboratory tests & Case 1 & Case 2 & Reference ranges \\
\hline Hematocrit & $57 \%$ & $40 \%$ & $41 \%-51 \%$ \\
\hline Platelet count & 58,000 & 286,000 & $143 \times 10^{3} / \mathrm{mm}^{3}$ to $450 \times 10^{3} / \mathrm{mm}^{3}$ \\
\hline Hemoglobin & 19.3 & 13.8 & 14 to $18 \mathrm{~g} / \mathrm{dl}$ \\
\hline White blood cell count & 15,300 & 5,700 & $4.5 \times 10^{3} / \mathrm{mm}^{3}$ to $10 \times 10^{3} / \mathrm{mm}^{3}$ \\
\hline Neutrophil count & 11,934 & 3,021 & $2,295 / \mathrm{mm}^{3}$ to $6,000 / \mathrm{mm}^{3}$ \\
\hline aPTT & 39.15 & - & 22.7 to $31.8 \mathrm{~s}$ \\
\hline PT & 15.80 & - & 10 to $14 \mathrm{~s}$ \\
\hline PT & 1.38 & - & 1.00 to $1.08 \mathrm{INR}$ \\
\hline$\gamma$-GT & 136 & - & 5 to $38 \mathrm{U} / 1$ \\
\hline $\mathrm{Na}$ & 129 & - & 136 to $145 \mathrm{mmol} / \mathrm{l}$ \\
\hline K & 3.2 & - & 3.5 to $5.1 \mathrm{mmol} / \mathrm{l}$ \\
\hline CK-MB & 40.2 & - & 0 to $25 \mathrm{U} / 1$ \\
\hline AST & 162 & 124 & 11 to $39 \mathrm{U} / 1$ \\
\hline ALT & 88 & 80 & 11 to $45 \mathrm{U} / \mathrm{l}$ \\
\hline $\mathrm{pH}$ & 7.09 & - & 7.32 to 7.42 \\
\hline $\mathrm{PO}_{2}$ & 47.7 & - & 80 to $100 \mathrm{mmHg}$ \\
\hline $\mathrm{PCO}_{2}$ & 46.2 & - & 36 to $46 \mathrm{mmHg}$ \\
\hline Bicarbonate & 13.8 & - & 22 to $26 \mathrm{mmol} / \mathrm{l}$ \\
\hline $\mathrm{O}_{2} \mathrm{SAT}$ & 68.9 & - & $>90 \%$ \\
\hline Creatinine & 1.42 & 0.63 & 0.40 to $1.30 \mathrm{mg} / \mathrm{dl}$ \\
\hline Urea & 26 & 33 & 15 to $42 \mathrm{mg} / \mathrm{dl}$ \\
\hline Creatine phosphokinase & 711 & - & 26 to $189 \mathrm{U} / 1$ \\
\hline Blood culture & - & Absence of anaerobic $\mathrm{M} \varphi$ & Negative growth of $M \varphi$ \\
\hline Hantavirus serology & IgM positive & IgM positive & Negative \\
\hline Dengue serology & IgM Negative & IgM Negative & Negative \\
\hline Leptospirosis serology & - & IgM Negative & Negative \\
\hline Yellow fever serology & IgM Negative & - & Negative \\
\hline HIV serology & Negative & - & Negative \\
\hline
\end{tabular}

Bold type indicates results outside reference ranges.

aPTT: activated partial thromboplastin time; PT: prothrombin time; PT (INR): protbrombin time (international normalized ratio); $\gamma$-GT: gamma-glutamyltransferase; CK-MB: creatine kinase MB-fraction; AST: aspartate transaminase; ALT: alanine transaminase; $O_{2} S A T$ : oxygen saturation; M $\varphi$ : microorganism; IgM: Immunoglobulin M; HIV: buman immunodeficiency virus. 


\section{CASE 2}

A 32-year-old married male pig farmer of mixed race, exsmoker, resident in the rural area of Jataí (but born in Pancas, state of Espírito Santo), searched medical care at CMSSC on September 25, 2012, three days after the onset of symptoms (fever, myalgia, arthralgia, headache, chest pain, cough, hypoxia, and acute respiratory failure) (Figures 1 to 4). The patient came from the same place as Case 1 patient, and was involved in several risk activities associated with hantavirus infection: deforestation; wood chopping; cleaning sheds, wharehouses, store rooms; among others. He also reported direct or indirect contact with rodents. Several laboratory tests were carried out (Table) and treatment with Tamiflu ${ }^{\circledR}$, Amplacilina ${ }^{\circledR}$ and Rocefin ${ }^{\circledR}$ was administered.

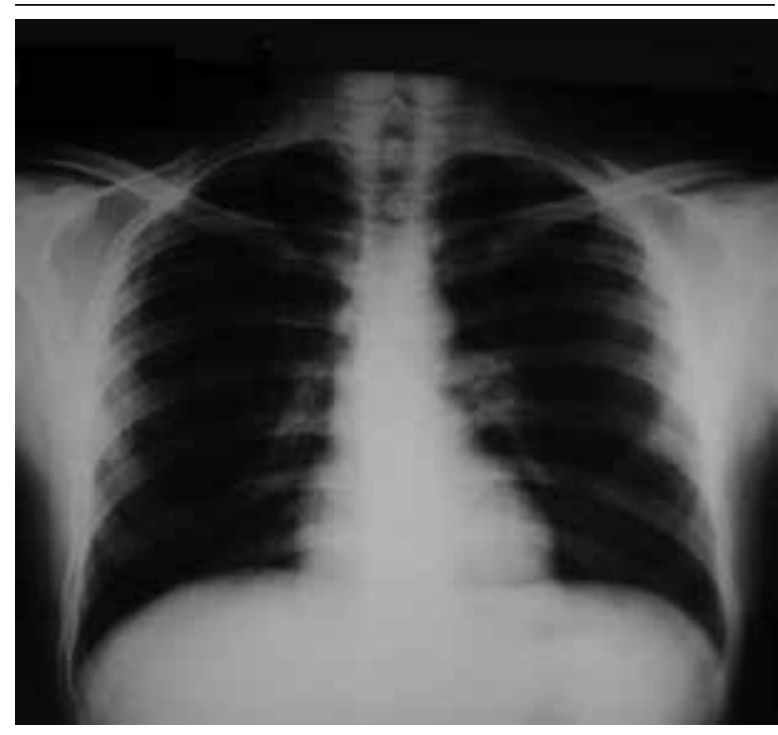

FIGURE 1 - Chest radiographic image of Case 2 patient at hospital admission

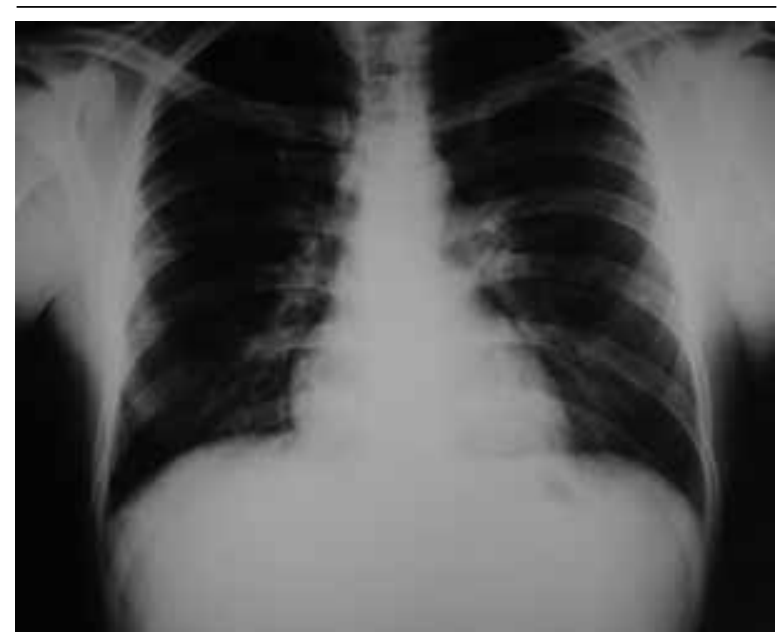

FIGURE 2 - Chest radiograph of Case 2 patient on day 3. A slight pulmonary edema with bilateral alveolar-interstitial infiltrate is observed

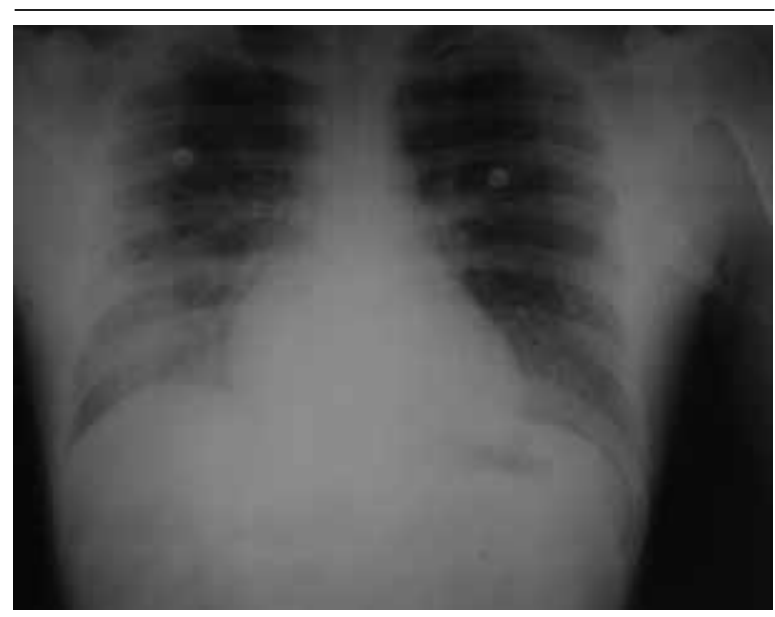

FIGURE 3 - Chest radiograph of Case 2 patient on day 4. The image reveals a diffuse pulmonary edema with dense alveolar-interstitial infiltrate

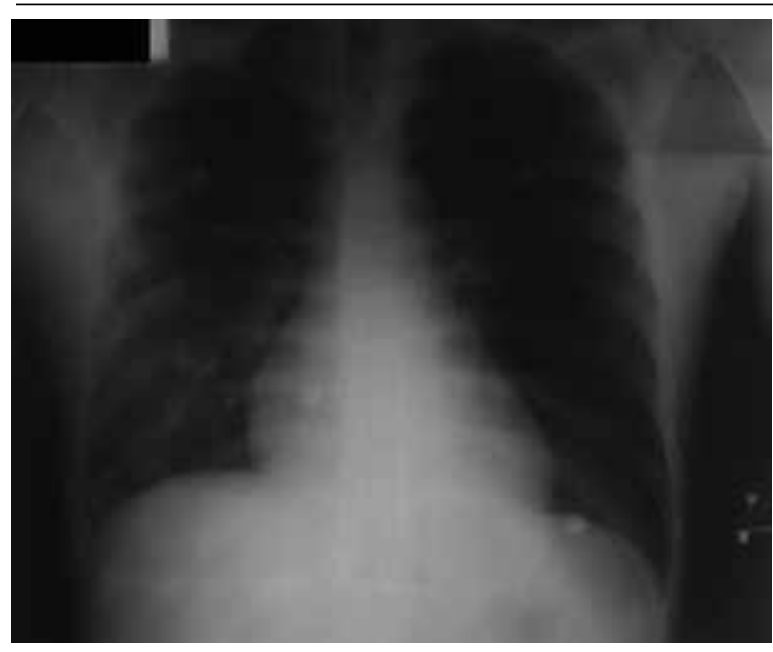

FIGURE 4 - Chest radiographic image of Case 2 patient on day 6, showing regression of the bilateral alveolar-interstitial infiltrate

Due to the worsening of the patient's clinical status, evolving to severe dyspnea, fever, chest pain, besides alterations in pulse, oxygenation, blood pressure and gasometry, he was referred to UCI, and mechanically ventilated. After a 9-day hospital stay, clinical improvement took place and laboratory results returned to normal ranges, as the patient entered the convalescent phase.

\section{DISCUSSION}

The patients in this study presented clinical pictures similar to those of acute respiratory distress syndrome (ARDS). Supportive treatment (like respiratory supports, the use of antibacterials and Tamiflu ${ }^{\circledR}$ ) is the absolute indication for ARDS of any suspected etiology ${ }^{(14)}$. Thus, given the possible severe evolution, immediate intervention is required: one should not wait for laboratory results to act. 
Because HCPS presents as a clinical condition similar to $\operatorname{ARDS}^{(18,20,21)}$, Ketai et al. ${ }^{(12)}$ sought to determine if radiographs of HCPS and ARDS patients could distinguish between these two clinical conditions. Their hypothesis was confirmed, however, accuracy is increased by the use of serial radiographs and more highly trained professionals. Besides, according to chest X-rays, interstitial pulmonary edema was observed in most HCPS patients, being a less common finding in ARDS ${ }^{(11)}$.

The suspicion of HCPS involves several clinical, epidemiological and laboratory parameters. The non-specific symptomatology, or prodromal phase, culminates with the onset of fever, intense headache, myalgia and abdominal pain ${ }^{(46)}$; whereas in the cardiopulmonary phase we can observe dry cough, tachycardia, tachydyspnea, and hipoxemia. As a consequence, a differential diagnosis is necessary to distinguish hantavirus infection from other diseases, such as leptospirosis, influenza, dengue fever, yellow fever or several pneumonias ${ }^{(47)}$. One of the methods usually employed is chest radiograph, which has been of help in the diagnostic suspicion of hantavirus disease and in the prognosis of patients with $\mathrm{HCPS}^{(10-13,17,18,20,21)}$. However, confirmation is obtained principally by means of IgM serology ${ }^{(8,21)}$.

Figueiredo et al. ${ }^{(5)}$ have analysed the laboratory aspects of confirmed cases of HCPS, in which they verified high hematocrit levels (> 55\%), leukocytosis $\left(>15,000 / \mathrm{mm}^{3}\right)$ and thrombocytopenia in most of the patients. On the other hand, in some individuals these altered laboratory parameters did not correlate well, as in Case 2, which presented hematocrit of $40 \%$ and low platelet count of $83,000 / \mathrm{mm}^{3}$, verified days after admission.

The serological assay ELISA for hantavirus detects the presence of specific antibodies in samples. In Brazil, the antigen used in the ELISA is the $\mathrm{N}$ recombinant protein of Araraquara virus. This method, as well as the molecular methods, presents high specificity and sensibility ${ }^{(8,15)}$, but not all laboratories have support or demand to employ it, so suspicious samples are referred to reference laboratories ${ }^{(19)}$. Notifiable diseases, such as hantavirus disease, need a quality diagnosis reference system, with samples being referred to central laboratories of Fundação Oswaldo Cruz (FIOCRUZ), Instituto Evandro Chagas (IEC) and Instituto Adolfo Lutz (IAL). In spite of the adequate procedures involving the diagnosis of acute hantavirus infection, the results obtained by these centers are jeopardized from failure to establish an early diagnosis still at hospital, what could improve patients' survival.

Pathogenesis of HCPS involves hiperresponsiviness of the immune system. Hantaviruses have been shown to have tropism for certain endotelial cells of pulmonary capillaries, through $\beta_{3}$ integrin receptors, also present on platelets. By the viral infection of these cells, there are stimuli to the secretion of chemokines. These attract $\mathrm{CD}^{+}$ lymphocytes that, when activated, stimulate the secretion of tumor necrosis factor (TNF) and interleucin-1 (IL-1), which have systemic action, activating endothelial cells and inducing macrophages to secret more chemokines. In the of cytokine cycle, large amounts of TNF are produced, resulting in shock ${ }^{(6,10,13)}$.

Gavrilovskaya et al. ${ }^{(9)}$ have recently evaluated the role of cytokine vascular endothelial growth factor (VEGF) in the pathogenesis of HCPS during the acute phase. Their observations confirm that hantavirus-infected endothelial cells are hiperresponsive to the effects of VEGF, considering that inhibition of $\beta_{3}$ integrin, which normally restricts VEGF-directed capillary permeability, is blocked by viral infection. Besides, VEGF is induced in hypoxic conditions, disrupting endotelial adherens junctions, increasing vascular permeability and, consequently, causing pulmonary edema.

In this study, the immediate search for medical help, associated to the clinical and epidemiological data of early suspicion of hantavirus infection in the second patient probably contributed to his convalescent outcome. We highlight the necessity of supplying the population with further information on the adoption of profilactic measures against hantavirus disease. We also draw attention to the importance of an early diagnosis, what will contribute to the adequate clinical management of HCPS.

\section{ACKNOWLEDGEMENTS}

To Fundação de Amparo à Pesquisa do Estado de Goiás (FAPEG) (call notice PPSUS 004/2010), to CNPq (Universal 483885/2010-0), to the medical team and to the laboratory staff of Centro Municipal de Saúde Dr. Serafim de Carvalho, to technique team of Núcleo de Vigilância Epidemiológica e Ambiental em Saúde, Jataí-GO.

\section{RESUMO}

A infecção por hantavírus, familia Bunyaviridae, provoca a síndrome cardiopulmonar por bantavírus (SCPH) nos países da América. Ela é uma antropozoonose, de elevada letalidade, que tem acometido preferencialmente indivíduos em contato com o meio rural, sendo transmitida por aerossóis a partir das excretas dos roedores silvestres infectados. 0 objetivo deste estudo foi relatar a ocorrência, quase que simultânea, de dois casos de SCPH ocorridos no município de Jataí, Estado de Goiás, Brasil.

Unitermos: hantavírus; infecções por hantavírus; sindrome pulmonar por hantavírus. 


\section{REFERENCES}

1. BAGAMIAN, K. H. et al. Transmission ecology of sin nombre hantavirus in naturally infected North American deermouse populations in outdoor enclosures. Plos One, v. 7, n. 10, p. 1-10, 2012.

2. BOLETIM eletrônico epidemiológico da hantavirose. Portal da saúde: SUS. Disponível em: <http://portal.saude.gov.br/portal/saude/ profissional/area.cfm?id_area=1558>. Acesso em: 26 set. 2012.

3. CAMPOS, G. M. et al. Síndrome pulmonar e cardiovascular por hantavírus: aspectos clínicos de uma doença emergente no sudeste brasileiro. Rev Soc Bras Med Trop, v. 42, n. 3, p. 282-9, 2009.

4. FERREIRA, M. S. Hantaviroses. Rev Soc Bras Med Trop, v. 36, n. 1, p. 81-96, 2003.

5. FIGUEIREDO, L. T. M.; CAMPOS, G. M.; RODRIGUES, F. B. Síndrome pulmonar e cardiovascular por hantavírus: aspectos epidemiológicos, clínicos, do diagnóstico laboratorial e do tratamento. Rev Soc Bras Med Trop, v. 34, n. 1, p. 13-23, 2001.

6. FIGUEIREDO, L. T. M. Febres hemorrágicas por vírus no Brasil. Rev Soc Bras Med Trop, v. 39, n. 2, p. 203-10, 2006.

7. FIGUEIREDO, L. T. M. Pneumonias virais: aspectos epidemiológicos, clínicos, fisiopatológicos e tratamento. J Bras Pneumol, v. 35, n. 9, p. 899-906, 2009 .

8. FIGUEIRED0, L. T. M. et al. Evaluation of a enzyme-linked immunosorbent assay based on Araraquara virus recombinant nucleocapsid protein. Am J Trop Med Hyg, v. 81, n. 2, p. 273-6, 2009.

9. GAVRILOVSKAYA, I.; GORBUNOVA, E.; KOSTER, F; MACKOW, E. Elevated VEGF levels in pulmonary edema fluid and PBMCs from patients with acute hantavirus pulmonary syndrome. Advances Virol, p. 1-8, 2012.

10. HJELLE, B.; TORRES-PÉREZ, F. Hantaviruses in the Americas and their role as emerging pathogens. Viruses, v. 2, p. 2559-86, 2010.

11. KETAI, L. H. et al. Hantavirus pulmonary syndrome: radiographic findings in 16 patients. Radiology, v. 191, p. 665-81, 1994.
12. KETAI, L. H. et al. Distinguishing hantavirus pulmonary syndrome from acute respiratory distress syndrome by chest radiography: are there different radiographic manifestations of increased alveolar permeability? J Thorac Imaging, v. 13, n. 3, p. 172-7, 1998.

13. KRUGER, D. H.; SCHÖNRICH, G.; KLEMPA, B. Human pathogenic hantaviruses and prevention of infection. Hum Vaccines, v. 7, n. 6 , p. 685-93, 2011.

14. MINISTÉRIO DA SAÚDE. Protocolo de manejo clínico de SRAG. Disponível em: <http://www.saude.rn.gov.br/content/aplicacao/sesap/ saude_destaque/enviados/protocolo_manejo_srag_03_03_10.pdf> Acesso em: 1 jun. 2013.

15. MORELI, M. L.; SOUSA R. L. M.; FIGUEIREDO, L. T. M. Detection of Brazilian hantavirus by reverse transcription polymerase chain reaction amplification of $\mathrm{N}$ gene in patients with hantavirus cardiopulmonary syndrome. Mem Inst Oswaldo Cruz, v. 99, n. 6, p. 633-8, 2004.

16. MORELI, M. L.; COSTA, V. G.; PARIZ, F. R. A seroepidemiological survey of hantavirus in Ilhéus county. Am J Virol, v. 1, n. 1, p. 18-23, 2012.

17. NOLTE, K. B. et al. Hantavirus pulmonary syndrome in the United States: a pathological description of a disease caused by a new agent. Hum Pathol, v. 26, p. 110-20, 1995.

18. SANTANA, R. C.; CAMPOS, G. M.; FIGUEIREDO, L. T. M.; FIGUEIREDO, J. F. Clinical and laboratory findings related to a favorable evolution of hantavirus pulmonary syndrome. Rev Soc Bras Med Trop, v. 39, n. 3 , p. 237-40, 2006.

19. SECRETARIA da Saúde do Estado de Goiás. Laboratório Central (LACEN). Disponível em: <http://www.saude.go.gov.br/index. php?idEditoria=4561>. Acesso em: 7 jun. 2013.

20. SIMPSON, S. Q. Hantavirus pulmonary syndrome. Heart Lung, v. 27, p. $51-7,1998$

21. SOUZA, D. M.; BRAGA, H. M.; TEIXEIRA, M. A. F.; CANELA, J. R. Síndrome cardiopulmonar por hantavírus. Rev Med Minas Gerais, v. 21, n. 2, p. 226-8, 2011

\section{MAILING ADDRESS}

Vivaldo Gomes da Costa

Rodovia BR 364, km 192; Parque Industrial 3.800; CEP: 75801-615; Jataí-G0, Brazil; e-mail: vivbiom@gmail.com. 